\section{SCOTTISH FISHERY RESEARCHES}

A PPENDIX $F$ of the Report of the Scottish Fishery Board contains a series of valuable papers with accurate and well executed plates. Dr. Stirling gives a preliminary report on "The Chemistry and Histology of the Digestive Organs of Fishes." The first part gives the results of chemical investigations of the digestive processes in the herring, cod, haddock, and skate. The second part deals exclusively with the intestinal tract of the herring. The muscular coat of the ossophagus consists of striped muscular fibres arranged more or less regularly at the upper part, but disposed circularly in several layers at the lower. The mucous membrane of the nesophagus has longitudinal folds, and is lined with cylindrical epithelium interspersed with numerous goblet cells. The oesophageal glands are simple tubular glands, with, at first, a very short secreting portion. The glands in the "cardiac sac," or "crop," arc, like those of the œesophagus, branched tubular glands lined in their upper part by tall columnar epithelium, and in their secretory parts by a single layer of cubical cells, like the "outer" cells of the fundus in mammals. The gland tubes become shorter towards the lower part of the cardiac sac, and they are absent in the pnemmatic duct, which is lined by a single layer of columnar epithelium, and divided into two compartments by folds of the mucous membrane. Dr. Stirling has found that the organ which has been hitherto known as the "crop" in the herring, is something more than a mere receptacle, and corresponds in structure and function to the cardiac portion of the stomach of higher vertebrates. There is a striking resemblance between the cells lining the secretory portion of the gland tubes and the "outer cells" in the mammalian stomach, the point of difference being that the tubes are lined by a single continuous layer of these cells. There are apparently no internal layers of cells comparable to the inner cells of mammals, and, as might be perhaps expected, the glands are simpler than those of the mammals, and without that differentiation of $i$ tissue which is brought about by specialisation of function. One cell may subserve two functions, and, from an evolutionist's point of view, the secretion of an acid and the formation of a ferment have not as yet in the fishes been relegated to two distinct sets of cells. The pyloric sac or stomach is that short tubular organ with thick muscular walls, and resembling a gizzard, which opens out of the crop and is continued jnto the intestine. The surface of the mucous membrane consists of irregular depressions, which are deeper than those of the cardiac sac and may be regarded as crypts. The pyloric sac is always lined by a very thick coating of mucus, which not only lies on the surface, but dips down into the pyloric crypts. The surface of the pyloric sac and the glands or crypts are lined throughout with a single layer of tall, narrow, columnar epithelium, having the same character as that which lines the gland ducts and the surface of the cardias sac. There is no muscularis mucosæ. The circular muscular coat is very thick, while the longitudinal is thin. Structurally the pyloric sac is comparable to the pyloric end of the mammalian stomach. Plates i. and ii. give series of figures illustrating various points in the anatomy of the intestinal part of the herring.

Prof. Macintosh gives a short note of preliminary observations made at the Marine Station, St. Andrew's, on the ova of various food fishes. Cod ova were specially examined, and experiments made as to their buoyancy and the effects of impure water, which proved very marked, and of changes of temperature. The small size of the yolk-sac, as well as the activity shown from the first by the newly-hatched fish show that they must soon take in nourishment from without. The ova of the common flounder were successfully hatched out. Other forms examined and experimented on were the long rough dab, turbot, Cyclopterus lumpus, herring, \&c., and amongst invertcbrates the ova of squids, Natica, whelk, nudibranchs, mussel, Asterias rubens, lobster, and shore-cral).

The vexed question as to whether the sprat is a separate species of the Clupeida or merely the young of the herring is satisfactorily settled in favour of the former opinion in the first part of the Report on the Sprat Fishing during the Winter of $1883-84$ by J. Matthews Duncan, F.R.S.E., in which definitions of the differences in external and internal characters are distinctly proved. The sprat is more graceful in shape and slightly thicke in body than the young herring. The dorsal surface of the head is proportionally slightly longer in the herring, the operculum therefore extending further back. The suboperculum in the sprat is shorter and more triangular. The lower jaw is always longer and the diameter of the eye rather larger in the herring. In both sprat and herring the lower edge of the belly from the anal fin forwards is covered by a series of scales, having a central longitudinal "keel" and two lateral rays projecting forwards and upwards. These are more numerous but weaker in the herring than in the sprat, where the central keel is stronger and the termination forms a sharp point, so that the difference can easily be felt. In the sprat the pelvic fin is anterior to the first ray of the clorsal, whilst in the herring it is posterior to it. The pectoral fin is placed proportionatcly further back in the herring, and the centre of the dorsal slightly behind the centre of the body. The position of the dorsal fin varies more in the sprat, the position of the anal fin more in the herring. The number of rays in the pectoral, dorsal, and anal fins is not constant in either species, but appears invariable in the pelvic fm, that of the herring having two rays more. The arrangement of the teeth in both species is the same on the maxillo, premaxilla, and tongue, but those on the tongue are smaller in the sprat, and the vomerine teeth present in the herring are entirely wanting. The same superiority, as far as number is concerned, shown by the herring in the fin rays, scales, \&c., is scen in comparison of other organs, the vertebræ, gill-rakers, and filaments, the branchial and pseudo-branchial filaments, and the branchiostegal rays, being all more numerous than in the sprat. The pyloric cæca are also more numerous. The slender duct by which the stomach (crop of Huxley, NATURE, vol. xxiii. p. 607 ) communicates posteriorly with the swim-bladder is slightly shorter and thicker in the sprat. In the herring the anterior end of the swim-bladder gives off two delicate branches, which run forward at first along each side of the parasphenoid, then diverge, and enter a small spindle-shaped capsule. From the anterior end of this capsule the duct passes out, and divides into two branches, one of which runs straight forward from the vesicle, whilst the other passes outwards at nearly a right angle. In the herring the ducts are very delicate tubes, measuring, in a herring I $20 \mathrm{~mm}$. long, $0.9 \mathrm{~mm}$. in diameter, and are surrounded by a cartilaginous sheath, $\cdot 25 \mathrm{~mm}$. in external diameter. The ducts mee posteriorly in the middle line, and open by a single aperture into the narrow anterior end of the swim-bladder. The spindleshaped capsule is about $1 \mathrm{~mm}$. Iong by $6 \mathrm{~mm}$. broad, and the spherical capsules are about $1.3 \mathrm{~mm}$. in diameter, the anterior one slightly larger. The sprat, however, shows a remarkablc departure from this arrangement. The ducts are ahout the samo size as, and their form and direction are similar to, those in the young herring, though, at the point where they diverge from the parasphenoid (about $5 \mathrm{~mm}$. from the swim-bladder) they lic higher, and are more difficult to follow. But the duct on each side ends in a sing/e capsule only, exactly similar to that of the herring, and it neither forms a spindle-shaped dilatation, nor gives off a branch to a second vesicle. Thus, while in the herring there are three vesicles on each side of the head, all containing air, in the sprat there is only one. The foregoing differences are so numerous and so constant at all seasons that there can be no question as to the sprat being a distinct species from the herring, a further proof being that the former is found with developed milt and roe. Mr. Matthews shows in Plate iii. the difference between sprat and herring in the shape of the body and the keel scales, in the size of the ova, and in the formation of the air-vesicles of the ear.

In the valuable paper on the "Natural History of the Herring" Prof. Cossar Ewart, Convener of the Scientific Committee, treats of the varieties of the herring, the migration, the spawning-ground, the process of spawning, and the artificial fertilisation and hatching of ova. The varieties of the herring have long been discussed in all countries frequented by this fish, and differences believed to exist not only between herring of different countries, but of different districts and seasons. How far this may be true could not be determined even by careful examination and figuring of over 500 specimens, taken at different parts of the coast during winter and spring. Comparisons of outline show not so much that the herring of one distric differ from those of another, but that there is a remarkable variation amongst herring caught at the same time. Heincke ("Varietäten d. Herings. Jahrb. d. Comm. in Keil, 1876-78") considers the position of the dorsal and pelvic fins of great importance, but, as specimens examined of the same length, caught at the same place, and as nearly as possible at the same stage of maturity, showed more difference than Heincke finds in his autumn and spring herring, some better character must be 
considered requisite. It seems unlikely that the same herring spawn twice a year, but that the fish which spawn in the spring and autumn of one year do not spawn again respectively till the spring and autumn of the next year, in which case it is difficult to account for two distinct races of herring. It may be stupposed that at first all herring were in the habit of spawning about the same period, but as time went on they were found spawning during every month of the year. Specimens of ova, for example, have been sent nearly every week from the Aberdeenshire coast, showing that herring have been spawning uninterruptedly in one district for at least ten months, from August I883 to June I884. The explanation of why at the present day there are two great spawning periods is not that spring and autumn are the two best periods for the depositing and hatching of the eggs, but that these are the two most favourable periods for the appearance of the fry, as then the surface-forms on which they feed are more abundant, as examination of the Ballantrae Bank showed. In the case of the herring the number of individuals does not depend so much on the number of eggs hatched as on the number of fry that survive. These when hatched are at first protected by their minute size and great transparency, and, given sufficient food, are likely to pass safely through the larval stage. If the larval food were more abundant in autumn and in spring, more fry would naturally survive at these periods, and this would ultimately result in the formation of great shoals of autumn and spring herrings. All that has been written on the migration of the herring leaves us still very much in the dark as to either the extent or the causes of it. Meantime, we may suppose that the movements of the herring are regulated during a greater part of the year by the supply of food, which naturally renders their movements very inconstant, and during the rest of the year by what may be termed their spawning instinct. This seems to imply several things, but it specially leads the herring to select ground suitable for the deposit of eggs, waters having a suitable depth, and water which will provide abundant food for the young fry. It has been long known, and was placed beyond doubt by the Fishery Board investigations of $\mathbf{1} 862-63$, that herring were wont to spawn on hard ground. A very complete survey of the Ballantrae not only corroborated this fact, but showerl that the herring even preferred to deposit their ova in the basin-shaped gravel-coated areas, where presumably the water is stiller than over the stone-covered ridges, and where it covered many square yards with a layer nearly half an inch in thickness. Eggs were also often found arranged in low masses over the surface of the long stems of laminaria. In several instances the dredge had apparently come upon part of the bank where the eggs lay " to a very great depth," but on examination it was found that the spawn, instead of forming thick masses, was arranged in irregular heaps ranging from a quarter to half an inch in thickness, and varying in size from scarcely an inch to nearly six inches square. By laying the portions side by side in a tank it was possible to obtain a very accurate notion of the arrangement of the undisturbed ova, which certainly often form a regular layer covering several yards of the bottom. On the east coast, judging from the specimens brought up by the long-line fishermen, the herring seem to select hard ground plentifully covered with sea firs, especially IJdrallmannia and Antennularia. Fishermen and others believe that there is some relation between the herring deserting any given spawningground-such as the once much-frequented bank off Dunbar and the equally famous Guillam Bank in the Moray Firth - and the loss of herring-nets during storms, or when over-fished. The reason is that nets loaded with putrefying fish, when left on the ground, cause the herring to seek more agreeable banks elsewhere. This pollution would be continued and extended by portions of the net continuing to fish during the whole scason, so that not only might the eggs first deposited be destroyed, but fish which might have spawned on other portions of the bank be taken, and their eggs, though shed, rendered useless. In this way not only the greater part of a shoal, but, what is of even greater importance, nearly all the eggs deposited during the spawning period might be destroyed, and the survivors of the comparatively small brood hatched desert their birthplace as spawning-ground and cast in their lot gregariously with the first large shoal they met with. In the artificial fertilisation and hatching of herring ova the natural process of spawning was followed as far as possible, and many thousands of eggs treated in this way on March 8 hatched out on March 28, 29, and 30 , the temperature varying from $4 \mathrm{I}^{\circ}$ to $44^{\circ} \mathrm{F}$. When the eggs had been plentifully supplied with pure water, the extremely active embryos kept revolving or wriggling inside the capsule, till this ruptured and allowed the larval herring to escape head-foremost. But if the supply of pure water had been limited, the capsule gave way prematurcly, the long, slender body cscaped, but the head remained within, and the embryo usually perished in spite of all efforts to escapc. The hatching was greatly expedited by the temperature of the water being slightly raised. As soon as the fry escape, they begin to try and ascend towards the surface, which they generally succeed in reaching on the fourth day, when they are found swimming freely about. This instinctive desire to rise to the surface as soon as they escape from the cggcapsule is evidently intended to bring $1 \mathrm{hem}$ to the vicinity of the food, on which, after the fourth or fifth day, they depend for nourishment. Sketches are given (Plates iv. v.) of herring, illustrating the different positions of the fins. A map of the Ballantrae spawning-bank (Plate vi.), and drawings of a colony of Hydrallmannia falcata (Plate vii.) and Antennuluria antennina (Plate viii.), with cluster of eggs attached. A series of figures (Plate ix.) show the eggs deposited artificially on glass and naturally on stones, gravel, and on a lost net dredged at Ballantrae.

A number of interesting specimens received by the Board are likewise described and figured:--(I) A new Blenny (Lumpenus lampretaformis, Plate $\mathrm{x}$. ), believed to be the first specimen recorded from the shorcs of the British Isles; it measured $10 \%$ inches in length, and was taken in forty fathoms of water, fifteen miles off St. Abb's Head. (2) A fine Torpdo nubiliana (Plate xi.) taken off Lybster in forty fathoms of water. (3) A Comber (Serannus cabrilla, Plate xii.) taken off Shetland, the first recorded in the North Seas. (4) A Turbot (Rhombus maximus, Plate xiii.), dark on both sides, with an eye on each side of the head and rounded frontal process, taken off Anstruther. (5) A splendid Opah (Lampris luna), four feet in length, taken in seventy-five fathoms of water off Fluga, Shetland, and now being examined by Prof. 'Tu' ner, F.R.S. Another item is a list compiled by Miss Maclagan of edible British fishes and mollusks, with their Latin, French, Italian, and German synonyms.

\section{THE BRITISH ASSOCIATION \\ Section D-Biology \\ Department of Zoology and Botany}

Remarks on the Characteristic Features of North American Vegetation, by Prof. Asa Gray.-The first impression produced on a visitor from Europe to the Atlantic coast would be the similarity of the flora to that of England, many of the plants being almost or quite the same. The larger number of these are obviously introduced. The mullein, the toad-flax, the ribworts, the milfoil, the clovers, thrive by every roadside as in England, and perhaps with even greater luxuriance, the competition being less. This strongly suggests the idlea that the distribution of plants is not always due so much to adaptation as to opportunity. As one proceeds westward and southward, the difference becomes more marked, the European type gradually disappearing. But as European settlements extend, the settlers carry their plants with them, and the plants are well up to the time, and travel by rail. On the other hand, some plants, but a much smaller number, are carried from America to Europe, and naturalised there. Such are Imfatirns fulva and Erigeron canadensis. Turning from similarities to differences, one of the first points that strikes a European visitor is the great wealth of trees and shrubs. This Prof. Gray illustrated by giving the number of European and North American species in the most important arborescent orders. The reason of this is probably to be found in the different conditions of the two continents during the period of glaciation. The flora of Europe is exceptionally poor in trces, and, on the return of a warmer climate, the return northwards of those that survived in the south was barred by the Mediterranean. The fossil remains of trees belonging to many tropical orders are found in our Miocene and Pliocene strata. In Anserica, on the contrary, there was nothing to prevent their gradual return from the south, and accordingly we find solitary examples, or in some cases a larger number of representatives, of many tropical orders among the trees of the Northern Statcs. Such are Menistermum (Menispermacer), Liriodendron (Magnoliaceæ), Diospyros(Ebenaceæ), Tecoma (Bignoniacex), and many others. This difference is also promoted by the greater heat of the American summer as compared with that of Europe. On the high lands of North America are also many Arctic plants, which 